\title{
Indirect Spectrophotometric Determination of Tolnaftate in Pharmaceutical Preparations
}

Nief Rahman Ahmed

The State Company For Drug Industries and Medical Appliances

\section{Thair Tahssen}

Received

$26 / 11 / 2007$

Mosul-Iraq

الخلاصة

تم تطوير طريقة طيفية غير مباشرة وذات حساسية عالية لتقدير التولنافتيت في بعض

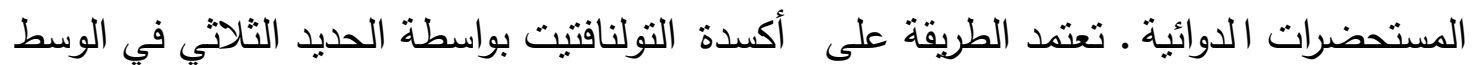
الحامضي حيث يختزل الحديد الثلاثي إلى الحديد الثنائي والذي بدوره يقترن مع فيروسيانيد

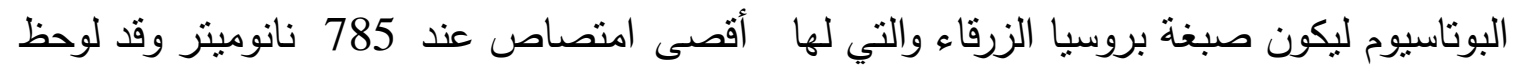

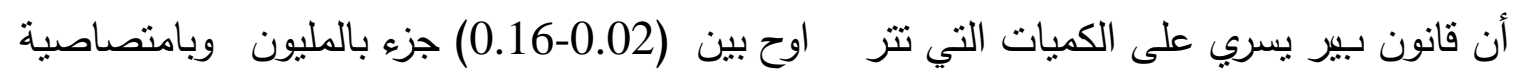

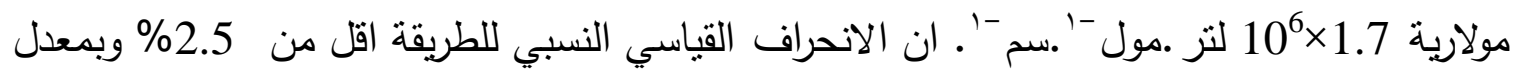
استرجاعية 100.3\% ولقد تم دراسة الظروف المتلى لتكوين المعقد منل درجة الحرارة وفترة التسخين وتراكيز الكوانثف والمتداخلات وطبقت الطريقة بنجاح في تقدير التولنافتيت في بعض المستحضرات

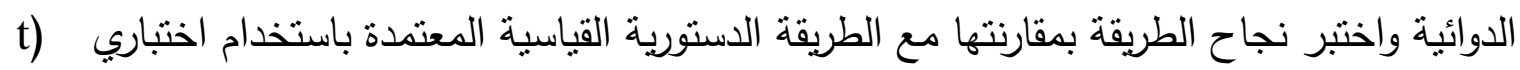
و) وعند حدود ثقة 95\% مما يدل على صلاحية التطبيق التحليلي للطريقة.

\section{$\underline{\text { Abstract }}$}

A highly, sensitive, indirect spectrophotometric method has been develop for the determination of tolnaftate in pharmaceutical preparations. The method is based on the oxidation of tolnaftate with $\mathrm{Fe}$ (III) in acidic medium. Fe (III) subsequently reduces to $\mathrm{Fe}(\mathrm{II})$, which is coupled with potassium ferricyanide after heating for 10 minutes at $70{ }^{\circ} \mathrm{C}$ to form prussian blue and the absorbance of the product was measured at $785 \mathrm{~nm}$ against a 
reagent blank. Beer's law was obeyed in the range of 0.02-0.16 ppm with molar absorptivity of $1.7 \times 10^{6} \mathrm{~L} \cdot \mathrm{mol}^{-1} . \mathrm{cm}^{-1}$, relative standard deviation of the method was less than $2.5 \%$ and accuracy (average recovery \%) was $100.3 \%$. The effect of various factors such as temperature, heating time,concentration of reagents, and interferences were investigated to optimize the procedure. The proposed method has been applied for the determination of tolnaftate in pharmaceutical preparations (quadrim cream and topical solution). A statistical compartsion of these results with those of official method shows good agreement using " $t$ " and " $F$ " test at 95\% confidence level. the results indicated that there is no systematic error and the present method has good validity.

Keywords: Tolnaftate, spectrophotometric, pharmaceutical preparations

\section{Introduction:}

Tolnaftate: (o-naphthalen -2-yl methyl (3-methyl phenyl) thiocarbamate.(I)<smiles>Cc1cccc(N(C)C(=S)Oc2ccc3ccccc3c2)c1</smiles>

$\mathrm{C}_{19} \mathrm{H}_{17} \mathrm{NOS}=307.4$

(I)

Has been widely used as a kind of topical antifungal in the treatment of cutaneous disease such as Jock itch, athlete's foot $(1,2)$ and other skin infections due to ,Epidermophyton floccosum, microsporum and uinii, M. canis and T. verrucosum $(3,4)$.Tolnaftate has been shown tobe an inhibitor of squalene epoxidase in susceptible fungi, it is therefore classified with allylamines(5) Very few methods have been reported for the determination of tolnaftate in pharmaceutical formulations, these methods include HPLC, UV spectrophotometry (6-8), a survey of literature revealed that only two visible spectrophotometric methods are reported $(9,10)$, the oxidative coupling reaction of tolnaftate with 2,6-dichloroquinone-4-chloromide to produce a chromophoric acid with $\lambda \max$ at $490 \mathrm{~nm}$ or coupling reaction with the $\mathrm{N}$-chloroquinone diimine to give a colored product with $\lambda \max$ at $530 \mathrm{~nm}$ and spectofluorimetry (11), however these methods lack sensitivity, and simplicity needed for routine analysis . in this paper we described a precise 
and accurate method for spectrophotometric determination of tolnaftate in pharmaceutical preparation by using iron (III) with ferricyanide.

\section{EXPERIMENTAL}

\section{Apparatus :}

A Spectro scan $50 \mathrm{UV}$ visible spectrophotometer with $1.0 \mathrm{~cm}$ quartz cells and CFL1083 water bath were used.

\section{Reagents :}

All chemicals used were of analytical grade and the tolnaftate standard material was provided from state company for drug industries and medical appliance (NDI) Ninavah-Iraq.

\section{Tolnaftate stock solution (100 ppm).}

This solution was prepared by dissolving $0.1 \mathrm{gm}$ of Tolnaftate in 200 $\mathrm{ml}$ methanol and diluting to $1 \mathrm{~L}$ with distilled water.

\section{Tolnaftate standard solution (1ppm).}

This solution was prepared by diluting $1 \mathrm{ml}$ of stock solution into $100 \mathrm{ml}$ by distilled water in a volumetric flask.

\section{Ferric chloride solution $0.1 \%$}

This solution was prepared by dissolving $0.1 \mathrm{gm}$ of ferric chloride in $100 \mathrm{ml}$ of water containing $2 \mathrm{ml}$ of concentrated $\mathrm{HNO}_{3}$.

\section{Potassium ferricyanide solution $0.1 \%$}

\section{Acetic acid solution 1N}

\section{Recommended procedure:}

A liquots of standard solution of tolnaftate $(0.5-4.0 \mu \mathrm{g})$ were transferred into a series of $25 \mathrm{ml}$ calibrated flasks, added $2 \mathrm{ml}$ of $1 \mathrm{~N}$ acetic acid, $6 \mathrm{ml}$ of $0.1 \%$ ferric chloride solution and $6 \mathrm{ml}$ of $0.1 \%$ potassium ferricyanide solution the flasks was immersed in water bath $\left(70{ }^{0} \mathrm{C}\right)$ for 10 mint, cool and make up to $25 \mathrm{ml}$ in volumetric flasks with water. The absorbance was measured at $785 \mathrm{~nm}$ against a reagent blank.

\section{Procedure for pharmaceutical preparations:}

\section{Cream:}

$1 \mathrm{gm}$ of cream, equivalent to about $10 \mathrm{mg}$ of tolnaftate was transfered to a $250 \mathrm{ml}$ separator containing about $75 \mathrm{ml}$ of chloroform. The chloroform solution successively washed with two $25 \mathrm{ml}$ portions of $0.1 \mathrm{~N} \mathrm{NaOH}$, two $25 \mathrm{ml}$ portions of $0.1 \mathrm{~N} \mathrm{HCl}$ and $25 \mathrm{ml}$ of water. The chloroform layer was 
filtered through a chloroform-washed cotton pledget into a $100 \mathrm{ml}$ volumetric flask. Chloroform was added to volume, and mix. $1 \mathrm{ml}$ of chloroform solution was evaporated on a steam bath just to dryness and the residue was dissolved in $20 \mathrm{ml}$ of methanol and diluted up to $100 \mathrm{ml}$ with distilled water (7). $3 \mathrm{ml}$ of this solution was treated as mentioned under recommended procedure.

\section{Topical solution}

$0.1 \mathrm{ml}$ of solution containing $1 \mathrm{mg}$ of tolnaftate was transferred into $1 \mathrm{~L}$ volumetric flask and diluted up to mark with distilled water, a $3 \mathrm{ml}$ of this solution was treated as mentioned under the recommended procedure.

\section{Results and discussion}

Tolnaftate is oxidized in acidic medium by ferric chloride which subsequently reduced to $\mathrm{Fe}(\Pi)$ and immediately reacts with Potassimferricyanide. This way formerly termed Turubull's blue, it is now considered to be identical with Prussian blue $(12,13)$, which absorbs maximally at 785 $\mathrm{nm}$ as shown in Fig [1], the colorless reagent blank has practically negligible absorbance at this wavelength. And this wavelength was recommended for determination.

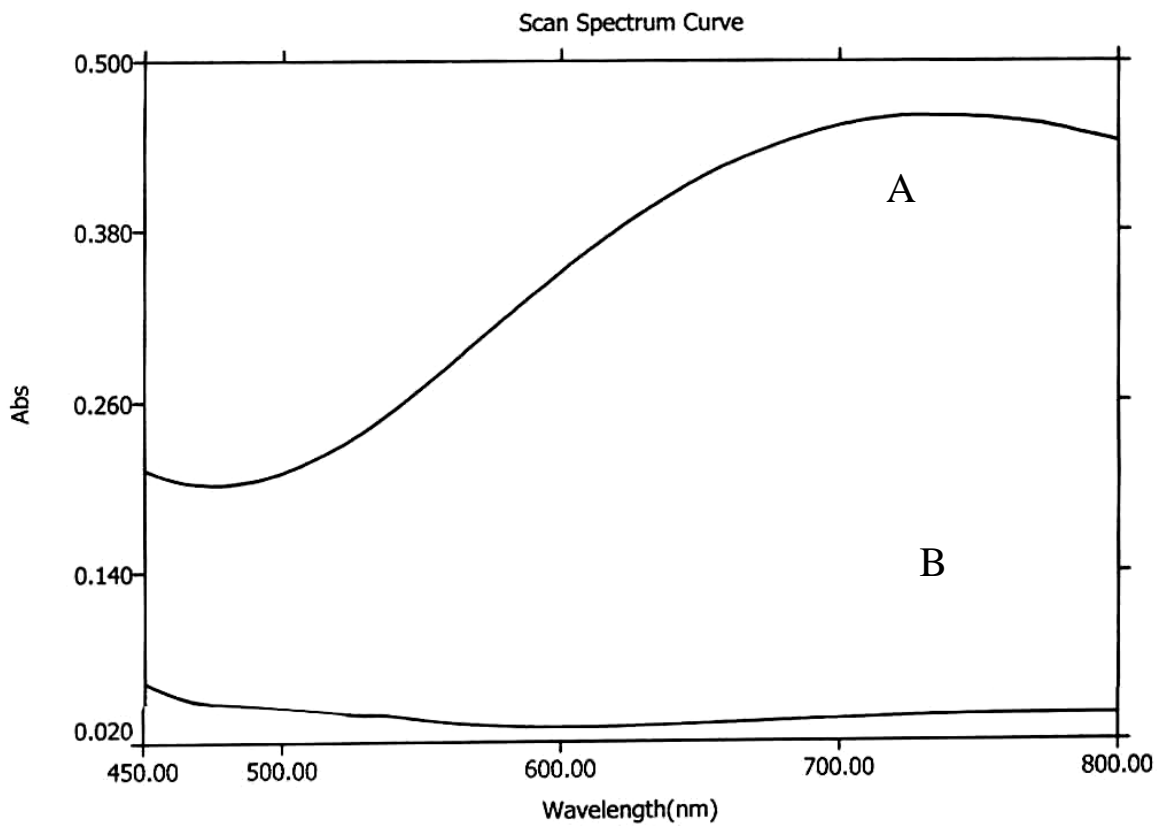

Fig. [1]: Absorption spectra of tolnaftate product against blank (A), with reagent blank against water (B) (tolnaftate taken $2 \mu \mathrm{g} / 25 \mathrm{ml}$ )

Study of the optimum reaction conditions 
The varios experimental parameters affecting the formation of colored product were optimized and used throughout the experiment. (Tolnaftate taken $2 \mu \mathrm{g} / 25 \mathrm{ml}$ ).

\section{Effect of acids}

The effect of different acids on the absorbance of the colored product is shown in table [1], which shows that maximum intensity was reached when using $2 \mathrm{ml}$ of acetic acid. This amount was selected for the subsequent experiments.

Table [1]: Effect of different acids on the absorbance of colored product.

\begin{tabular}{|l|ccccc|}
\hline \multicolumn{1}{|c|}{ Acids } & \multicolumn{5}{c|}{ Absorbancelml of acid added } \\
\hline $\mathrm{HCl})$ & 0.5 & 1 & 2 & 3 & 5 \\
$\mathrm{H}_{2} \mathrm{SO}_{4}$ & Turbid & Turbid & Turbid & Turbid & Turbid \\
$\mathrm{HNO}_{3}$ & Turbid & Turbid & Turbid & Turbid & Turbid \\
$\mathrm{CH}_{3} \mathrm{COOH}$ & 0.11 & 0.101 & 0.070 & 0.056 & 0.042 \\
& 0.070 & 0.180 & 0.428 & 0.428 & 0.430 \\
\hline
\end{tabular}

\section{Effect of the amount of ferric chloride reagent}

The amount of ferric chloride solution for maximal color intensity was examined. It was observed that the addition of $6 \mathrm{ml}$ of $0.1 \%$ ferric chloride solution was required to obtain a maximum absorbance table [2]. This amount was selected for subsequent work.

Table [2]: Effect of the amount of ferric chloride reagent.

\begin{tabular}{|l|ccccc|}
\hline Ml of 0.1\% ferric chloride & 2 & 4 & 6 & 8 & 10 \\
\hline Absorbance & 0.327 & 0.428 & 0.430 & 0.430 & 0.431 \\
\hline
\end{tabular}

\section{Effect of the amount of Potassium ferricyanide solution.}

The amount of Potassium ferricyanide solution for maximal color intensity was examined. It was observed that the addition of $6 \mathrm{ml}$ of $0.1 \%$ Potassium ferricyanide solution was required to obtain a maximum absorbance table [3]. This amount was selected for subsequent work.

Table [3]:-Effect of the amount of potassium ferricynide solution.

\begin{tabular}{|l|ccccc|}
\hline Ml of $0.1 \%$ potassium ferricyanide & 2 & 4 & 6 & 8 & 10 \\
\hline Absorbance & 0.376 & 0.419 & 0.430 & 0.430 & 0.432 \\
\hline
\end{tabular}

\section{Effect of temperature and heating time:}

The effect of temperature and heating time on the color intensity were studied in practice the absorbance of the color reached maximum after 10 
min at $70^{\circ} \mathrm{C}$, table[4]. The absorbance was then stable for at least $6 \mathrm{~h}$.

Table [4]: Effect of temperature and heating time.

\begin{tabular}{|l|ccc|ccc|lcc|}
\hline Temp ${ }^{\circ} \mathrm{C}$ & \multicolumn{3}{|c|}{50} & \multicolumn{3}{c|}{70} & \multicolumn{3}{c|}{90} \\
\hline Time (mint) & 10 & 20 & 30 & 10 & 20 & 30 & 10 & 20 & 30 \\
\hline Absorbance & 0.205 & 0.210 & 0.220 & 0.432 & 0.431 & 0.432 & 0.431 & turbid & turbid \\
\hline
\end{tabular}

\section{Effect of order of addition}

To test the effect of order of addition of the reagents on absorbance of the product, different orders were tested. The selected order was Tolanaftate, acetic acid, ferric chloride, followed by potassium ferricyanide solution.

\section{Beer's law}

The method obeyed Beer's law in the concentration range of 0.5-4 $\mu \mathrm{g} / 25 \mathrm{ml}$ with molar absorptivity of $1.7 \times 10^{6} \mathrm{~L} \cdot \mathrm{mol}^{-1} \cdot \mathrm{cm}^{-1}$. a regression analysis of Beer's law plot at $785 \mathrm{~nm}$ revealed a good correlation $(\mathrm{r}=0.9888$, $\mathrm{n}=8$ ) the graph of the absorbance versus the concentration of tolnaftate showed a low intercept (0.029) and slope (0.09), and is described by a regression equation. $\mathrm{Y}=\mathrm{ax}+\mathrm{b}$ (where $\mathrm{x}$ is the concentration of tolnaftate in $\mu \mathrm{g} / \mathrm{ml}, \mathrm{Y}$ is the absorbance, $\mathrm{a}$ is the slope and $\mathrm{b}$ is the intercept) and the limit of detection was evaluated as (14).

$\mathrm{LOD}=3.3 \frac{\mathrm{So}}{b}$

Where $\mathrm{b}$ is the slop and So is the standard deviation of the regression line. The limit of detection was $0.0039 \mu \mathrm{g} \cdot \mathrm{ml}^{-1} \quad(\mathrm{n}=8)$

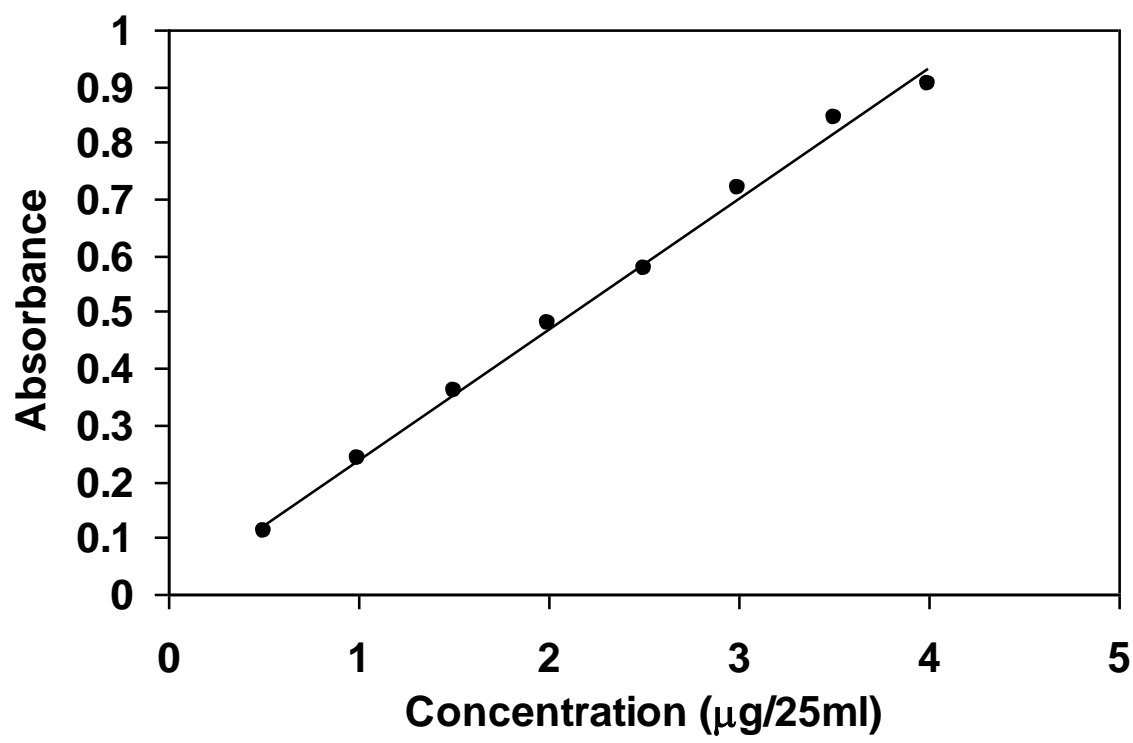

Fig [2]: calibration graph of tolnaftate.

\section{Accuracy and precision:}


The accuracy and precision of the method were established by analysing the pure drug at three different concentrations and seven determinations. The average recovery which is a measure of accuracy is $100.3 \%$ revealing high accuracy of the method. The relative standard deviation (RSD), which is an indicator of precision is less than $2.5 \%$ the results are cited in table [5].

Table [5]:- Accuracy and precision of the method

\begin{tabular}{|l|l|l|l|}
\hline \multicolumn{2}{|l|}{ Amount of tolnaftate $(\mu \mathrm{g} / 25 \mathrm{ml})$} & Recovery $(\%)$ & $\mathrm{RSD}(\%)$ \\
\hline Taken & Found & & \\
\hline 1 & 1.008 & 100.8 & \pm 2.33 \\
\hline 2 & 2.009 & 100.45 & \pm 1.15 \\
\hline 3 & 2.99 & 99.66 & \pm 0.84 \\
\hline
\end{tabular}

Stoichiometry of reaction:- The stoichiometry of reactants was investigated by the mole ratio method (15). The results obtained (fig 3) indicated the existence of 1:1:1 Tolnaftate- $\mathrm{FeCl}_{3}-\mathrm{K}_{3} \mathrm{Fe}(\mathrm{CN})_{6}$ at $785 \mathrm{~nm}$. Thus the suggested reaction might be written as $(13,16)$

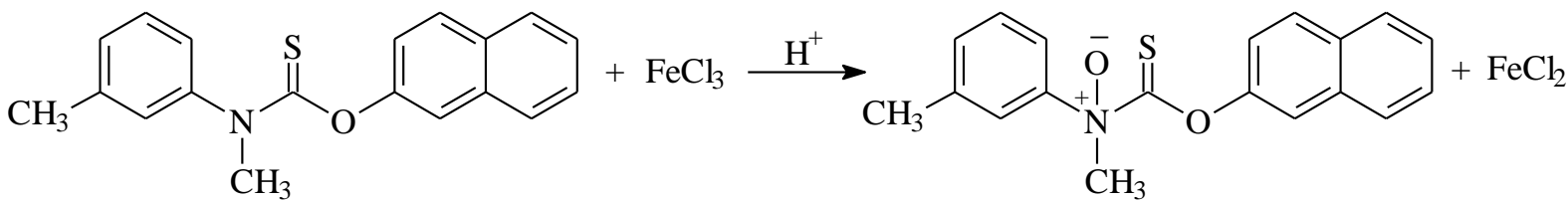

$\mathrm{FeCl}_{2}+\mathrm{K}_{3} \mathrm{Fe}(\mathrm{CN})_{6} \rightarrow \mathrm{KFe}\left[\mathrm{Fe}(\mathrm{CN})_{6}\right]+2 \mathrm{KCl}$

$$
\text { Prussian blue. }
$$

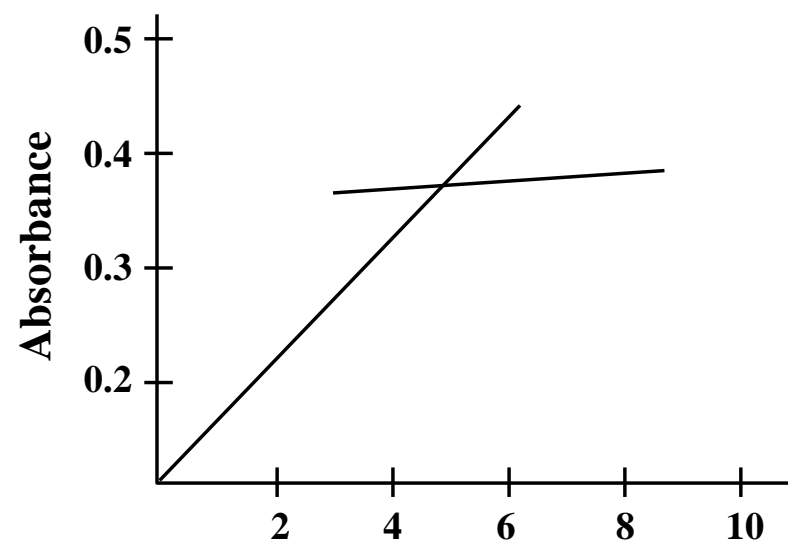

Mole ratio [Tolnaftate $\mathrm{K}_{3} \mathrm{Fe}(\mathrm{CN})_{6}$ ] at fixed amount of $\mathrm{FeCl}_{3}$

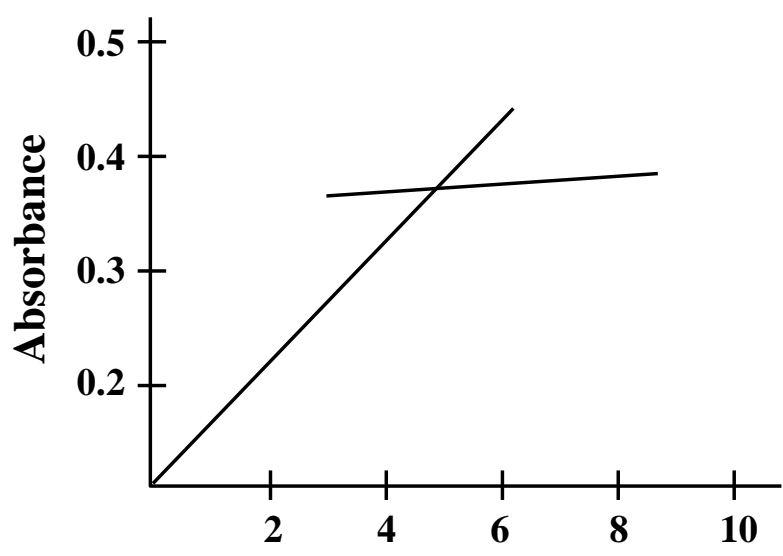

Mole ratio [Tolnaftate $\mathrm{FeCl}_{3}$ ] at fixed amount of potassium ferricyande solunon

Fig. [3] : Molar ratio method of toluaftate- $\mathrm{FeCl}_{3}-\mathrm{K}_{3} \mathrm{Fe}(\mathrm{CN})_{6}$

\section{Effect of interferences:}


The interfering effect of foreign species often accompanied with tolnaftate in the pharmaceutical preparations were studied by adding different amounts of foreign species to $3 \mu \mathrm{g} \backslash 25 \mathrm{ml}$ of tolnaftate in solution and the recommended procedure for the determination of tolnaftate was followed. The species are considered to interfere seriously if they cause a change of more than $2 \%$ in the absorbance obtained for tolnaftate a lone (17). It was observed that the Betamethazone 17-valerate, gentamycine sulphate and clioquinol don't interfere with determination method at levels found in the dosage form cited in table[6] so that the selectivity of method is very good.

Table [6]: determination of tolnaftate in presence of excipients.

\begin{tabular}{|l|c|c|}
\hline \multicolumn{1}{|c|}{ Excipients } & Amount taken $\mu \mathrm{g}$ & Averagerecovery $^{*} \%$ \\
\hline Betamethazon 17-valerate & 0.15 & 100.05 \\
\hline Gentamycine sulphate & 3 & 100.0 \\
\hline clioquinol & 3 & 100.08 \\
\hline
\end{tabular}

* Average of seven replicate analyses.

\section{Analytical application:}

Two types of drugs containing tolnaftate (cream and solution) were analyzed. The results of analysis of pharmaceutical formulations. Table[7] were compared statistically by student t-test and by the variance ratio F-test with those obtained by official method (7) at $95 \%$ confidence level. The calculated $\mathrm{t}$ and $\mathrm{F}$ values did not exceed the theoretical values indicating that there was no significant difference between the precision of the proposed and official methods.

Table [7]: Assay of Tolnaftate in pharmaceutical formulations.

\begin{tabular}{|c|c|c|c|}
\hline \multirow{2}{*}{$\begin{array}{c}\text { Pharmaceutical } \\
\text { preparations } \\
\text { supplied by NDI }\end{array}$} & \multicolumn{2}{|l|}{ Amount of tolnaftate } & \\
\cline { 2 - 4 } & Present method & B.P (official method) & Certified value \\
\hline Quadrim cream & $\begin{array}{c}10.02 \mathrm{mg} \backslash \mathrm{gm} \\
\mathrm{t}=1.43, \mathrm{~F}=1.23\end{array}$ & $9.96 \mathrm{mg} \backslash \mathrm{gm}$ & $10 \mathrm{mg} \backslash \mathrm{gm}$ \\
\hline Topical solution & $\begin{array}{c}9.98 \mathrm{mg} \backslash \mathrm{ml} \\
\mathrm{t}=1.88, \mathrm{~F}=1.08\end{array}$ & $10.06 \mathrm{mg} \backslash \mathrm{ml}$ & $10 \mathrm{mg} \backslash \mathrm{ml}$ \\
\hline
\end{tabular}

- Mean of six determinations.

t values $(\mathrm{n}=10$, at $95 \%$ confidence level tabulated value 2.262

$\mathbf{F}$ values ( $\mathrm{n} 1$ and $\mathrm{n} \mathbf{2}=10$, at $95 \%$ confidence level tabulated value 3.18

\section{REFERENCES:}


1. Chem. X., Jini X. New Pharmacology, Vol.12, People's Medical Publishing House, Beijing, 1985, P.146.

2. British Medical Association 2004, 47, 567.

3. The Pharmaceutical Codex, London. 1979, P.95

4. Delgado J. and Remer W., "Text Book of Organic Medical and Pharmaceutical Chemistry", $10^{\text {th }}$ Edn, Ausolters Kluwor company, philadelpha, 1998, P.191.

5. Ryder N., Frank I. and Dupout M., "Antimicrob Agents Chemother", 1986, 29, 856.

6. Cho G. and peng X., "Assay of tolnaftate in comparison on the pharmacy-eutical compound preparation", Laboratories of foods and drugs investing-ation report, 1985,3,47-52.

7. British pharmacopeia 2005, P.1644

8. The United State pharmacopiea convention, Inc, USP, 2001, 25.

9. Sastry p., Raoj S. and Krishna R., "spectrophotometric for the determina- tion of tolnftate", Talanta, 1993, 40, 571-576.

10. Khashaba Y., Shabouri El. R., Emara M. and Mohammed M., "Analysis of some antifungal drugs by spectrometric and spectroflurimetric method in different pharmaceutical dosage forms", journal of pharmaceutical and biomedical analysis, 2000, 22, 363-376.

11. Tang B., Wang X., Wang G. and Chem Z., Highly sensitive and selective spectrophotometric determination of tolnaftate through the formation of ternary iclusion complex of $\beta$-naphthol/ $\beta$-cyclodextrin/ anionic surfactant system, talanta, 2006, 69, 113-120.

12. Cotton F., Wilkinson G., Murillo and Bochman M., "The Elements of the first Transition series, in advanced inorganic chemistry, $6^{\text {th }}$ Edn, John Wiley and sons, Inc, New York, 1999, P.791.

13. Vogel A. I., A text-Book of Macro and semimicro Qualitative Inorganic Analysis, "4 ${ }^{\text {th }}$ Edn, Longman, 1974, pp. 261-264

14. Bassavaiah K. and Somashekar B. C. "Quantitation of rantidine in 
pharm-aceuticals by titrimetry and spectrophotometry using dichromate as the oxidimetric reagent". Journal of the Iranian Chemical Society, 2007, 4, 78-88.

15. Bouer H. H., Christion G. D. and Oreily J. E., "Instrumental Analysis," Allyn and Bacon, Inc, Boston, 1978, p.p.178-179.

16. Nagara P., Dinesh N., Gowda N. and Rangapp K., "Asimple spectrophotometric determineation of some phenothiazine drug in pharmaceutical samples", Analytical Scince, 2000, 16,1127-1131.

17. Hung S. Ch., Qu C. L. and Wu S. Sh., "Spectrophotometric Determination of Uranium with 2-(3,5) dibromo -2- pyridylazo -5diethylaminophenol in the presence of a nionic surfactant.Talanta, 1982, 29, 629-631. 